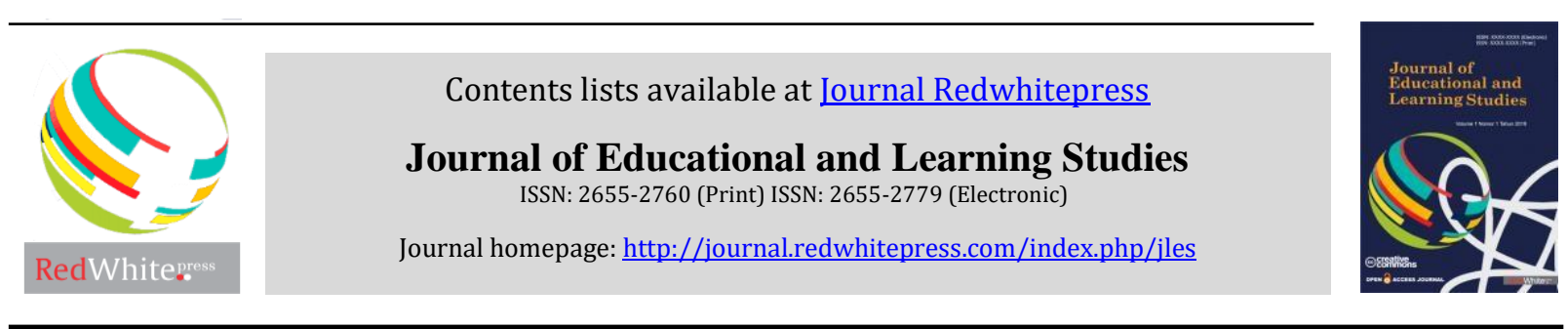

\title{
Utilizing mind-mapping to foster career exploration of high school students
}

\author{
Silvianingsih ${ }^{1^{*}}$, I Nyoman Sudana Degeng ${ }^{2}$, Triyono $^{3}$, Carolina Ligya Radjah $^{4}$ \\ 1, 2, 3,4 Universitas Negeri Malang, Indonesia
}

\begin{tabular}{l} 
Article Info \\
Article history: \\
Received March $12^{\text {th }}, 2019$ \\
Revised May $02^{\text {th }}, 2019$ \\
Accepted May $25^{\text {th }}, 2019$ \\
\hline
\end{tabular}

\section{Keyword:}

Mind-map

Career exploration

High school

\begin{abstract}
This study aims to determine the effect of mind-mapping to enhance high school's student career exploration in guidance group setting. This study use a single subject design with multiple baseline across subject models. The subjects of this study are eight (8) high school students in 10th grade. The data collection instruments in this study are the recording frequency of career exploration (sub components narrowing choices, specifies a vocational choice, and deciding an action implementation), career exploration skill instruments, and treatment instruments in the form of career guidance group guidebooks. The results shows that mind-mapping can be implemented to enhance the students career exploration skill, that is the all subjects' first sub component exploration skills (narrowing choices) in group data shows average baseline 13.27 increased to 30.86 ; the second sub component (specifies a vocational choice) shows average baseline 9.67 increased to 22.18; and the third sub component (deciding an action implementation) shows average baseline 13.42 increased to 20.26. The results affirm that the use of mind-mapping is effective to enhance the exploration skills of high school students.
\end{abstract}

(C) 2019 The Authors. Published by Redwhitepress.

This is an open access article under the CC BY-NC-SA license (https://creativecommons.org/licenses/by-nc-sa/4.0/

\section{Corresponding Author:}

${ }^{*}$ Silvianingsih

Universitas Negeri Malang, Indonesia

Email: ipiyupi.ssi@gmail.com

\section{Introduction}

Indonesia's educational system is facing a challenging state, where the institution of higher education that were meant to prepare prospective workers, seems to keep failing to do so. The state Central Bureau of Statistics shows that the unemployment that came from undergraduates keep on showing higher rate. In 2015, there were 565.402 of undergraduates unemployed, which became 567.235 in February, 2016. The number keep on increasing in 2017, where 618.758 undergraduates are becoming unemployed, and as much as 789.113 undergraduates become unemployment in February 2018 (Badan Pusat Statistik, 2018). (Hariani, 2011) stated that the data showed that $60 \%$ undergraduates are unemployed, and graduates who are employed not able to show the skills and working competence as expected by the industrial.

Among causes of the phenomena above is the discrepancy between the undergraduates skill, personal characteristics, and the major course of these prospective workers choose when they enrolled to higher education. (Harahap, 2014) informed that $87 \%$ Indonesian scholars were chosing the wrong department in their higher education institution. (Pascarella \& Terenzini, 1991) mentioned that the academic major has a significant impact on career opportunities and salaries. Choosing the suitable career will guide scholars to be an optimaldeveloped and skilled prospective workers in their future, as Pesch, Larson, and Seipel (2017) firmly stated that 
making a right career decision, will help scholars to pursue a career they find fulfilling and provides them with high levels of vocational satisfaction.

Choosing a major course in higher education had to be done at the end of high school's period. In Indonesia, the period of high school education is passed in 3 years, begins in $10^{\text {th }}$ grade and ends in $12^{\text {th }}$ grade. Before the student make a career decision in their $12^{\text {th }}$ grade, it is important for them to start exploring their career alternatives. Through career exploration, students could be provided with information on university's course requirements, various vocational programs available, and focused on gathering career information as well as learning the occupation names (Lau et al., 2011). High school counselors are obligated to escort their students to be well-informed of variety kind of occupations, to consider every advantages and disadvantages of different occupations for their future, and kinds of major department in higher education that congruent with those occupations.

School counselors can held career exploration program by utilizing interesting techniques and methods. Mind-mapping is one of visualizing technique that can help students gathers and memorizing relevant information in a creative and a fun way. (Davies, 2011) explain that a person can freely and spontaneously associate any idea in mind-mapping. This technique include students drawing all the career information that they already receive, using arrows to connect those information with other relevant concepts, and stating key word to give meaning to each concepts in the drawing.

Mind-mapping can be included in guidance group intervention, which address significant topics to help students develop any necessary skills and their competence in varied aspects. (Brown, 2018) mentioned that guidance group is an educational and preventive type of group. The purpose of the guidance program is to increase knowledge, so it is expected to minimalize the impact that possibly can occur from problems and improve one's function to anticipate possibly problems (Dewi et al., 2017).

Therefore, school counselors can develop a guidance group that utilizing mind-mapping technique that guide high school students to gather information of various occupation, various relevant-major in higher education, and higher education course requirements in a spontan, freely, and creative way.

\section{Method}

The research subjects of this study are $10^{\text {th }}$ grade high school students which were determined based on (1) low career exploration skills, (2) self-report form, (3) interviews with school's counselor. Level of the exploration skills determined by summing the students answers concerning of exploration skills' components that they have so far. Total answer $\leq 15$ means that the career exploration skills are at the category of low (unskilled); 16-35 are at the category moderate (skilled); and $\geq 36$ are the category of high (very skilled). Students in the range of low career exploration skills then screened through their answer on the open-questions about any alternative major and occupation to pursue in the meantime, and these conditions are crosschecked trough interviewing the school counselor. These steps are to make sure that researchers find the right subjects for the experiment. The subjects were the $10^{\text {th }}$ grade students of Brawijaya Smart School, which consists of 27 students and eight (8) students were obtained as research subjects.

The participant involve in the research was a school counselor, which (1) together with the researchers screen and determine the students that were obtained as research subjects; (2) the researchers teach the school counselor how to guide the guidance group to implement mind-mapping technique in career exploration; (4) together with the research will score the data collection in each session of the guidance group.

Target behavior in this research is career exploration which consists of three sub components: (1) narrowing choices, (2) specifies a vocational choice, and (3) deciding an action implementation based on the vocational choice that had been made. The target behavior refer to the concept of career exploration suggested by (Kosine \& Lewis, 2008).

The guidebooks and materials were prepared by the researchers. The guidebook consists of: (1) manual book for the school counselor leads the guidance group and how to teach the technical making of mind-map; (2) the career catalog that subjects can use as the information source about variety of occupations and major in higher education (subject are also allowed to use as many information they can gather from the internet). The materials were validated by experts. The experimental design of this study is single subject design with multiple baseline across subject's model with A-B-A' design (Creswell, 2012); (Sunanto et al., 2005). Phase A is baseline, it is the subjects in the group exploration skills condition before receiving any treatment. Phase $\mathrm{B}$ is an intervention using mind-mapping technique. Phase A' is maintenance phase, where the condition of exploration skills is observed after the intervention is done. Each phase consists of several sessions where the school counselor lead the guidance group and the researchers involved as observers and interviewers. Work sheets are 
given to the subjects in the end of each sessions. The evaluation and ratings of every work sheet based on the sub components of career exploration skills. In Phase B and A', school counselor implementing the manual book that was developed by researchers. In each sessions in these steps, students are guided to visualize their narrowing choices, specifies a vocational choice, and deciding an action implementation in a sheet of paper. Each of the sub components are drawn as the central circle, and students are freely to added several others circles and associates it with the three central circles. In the end of the sessions, each students will present their drawing to the researchers and explain their drawings, including all of the associations arrows. Students are allowed to revised their mind-mapping drawing in the next sessions if they felt they need some changes plan or goals, or added some new association-circles if they felt that they have new information, or even not to change any drawings that they had made in the previous session. Presentation are obligated to be done in the end of each session for the researchers rates the level of subjects career exploration skills at the time being. The scores than are analyzed and observed subjects as a group data of career exploration skills to understand more about the effect of mind-mapping technique for $10^{\text {th }}$ grader high school students.

\section{Results and Discussions}

The following Table 1 presents the results of the target students' group evaluation of the career exploration skills (sub component narrowing choices, specifies a vocational choice, and deciding an action implementation) measurements.

Table 1: Evaluation Results on Students Career Exploration Skills

\begin{tabular}{|c|c|c|c|c|c|c|c|c|c|c|c|c|c|c|}
\hline \multirow{3}{*}{ Sub Comp. } & \multirow{3}{*}{ Subject } & \multicolumn{13}{|c|}{ Phase } \\
\hline & & \multicolumn{4}{|c|}{ Baseline } & \multicolumn{4}{|c|}{ Treatment } & \multicolumn{5}{|c|}{ Maintenance } \\
\hline & & 3 & 4 & 5 & 6 & 7 & 8 & 9 & 10 & 11 & 12 & 13 & 14 & 15 \\
\hline 1 & 1 & 13 & 14 & 13 & 15 & 33 & 33 & 32 & 33 & 35 & 35 & 33 & 34 & 35 \\
\hline \multirow{7}{*}{ 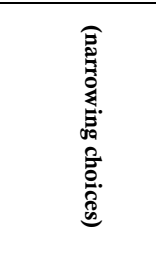 } & 2 & 13 & 13 & 14 & 13 & 30 & 31 & 32 & 33 & 34 & 34 & 33 & 34 & 34 \\
\hline & 3 & 12 & 13 & 12 & 12 & 26 & 27 & 26 & 28 & 30 & 31 & 30 & 30 & 30 \\
\hline & 4 & 14 & 13 & 13 & 13 & 30 & 31 & 30 & 30 & 31 & 32 & 33 & 32 & 30 \\
\hline & 5 & 13 & 13 & 14 & 13 & 32 & 33 & 33 & 34 & 35 & 35 & 34 & 35 & 35 \\
\hline & 6 & 13 & 14 & 14 & 13 & 30 & 31 & 30 & 31 & 32 & 33 & 34 & 33 & 33 \\
\hline & 7 & 13 & 13 & 14 & 15 & 30 & 31 & 32 & 33 & 34 & 34 & 35 & 34 & 33 \\
\hline & 8 & 14 & 13 & 13 & 13 & 27 & 28 & 27 & 28 & 29 & 30 & 31 & 30 & 30 \\
\hline \multicolumn{2}{|c|}{ Total of each session } & 105 & 106 & 107 & 107 & 238 & 245 & 242 & 250 & 260 & 264 & 263 & 262 & 260 \\
\hline \multicolumn{2}{|c|}{ Mean of each session } & 13.01 & 13.02 & 13.04 & 13.04 & 29.07 .00 & 30.06 .00 & 30.03 .00 & 31.02 .00 & 32.05 .00 & 33 & 32.09 .00 & 32.08 .00 & 32.05 .00 \\
\hline \multicolumn{2}{|c|}{ Total Mean of each phase } & \multicolumn{3}{|c|}{53.01 .00} & & \multicolumn{4}{|c|}{154.03 .00} & & \multicolumn{4}{|c|}{131.02 .00} \\
\hline \multicolumn{2}{|c|}{ Mean of each Phase } & \multicolumn{3}{|c|}{13.275} & & \multicolumn{4}{|c|}{30.86} & & \multicolumn{4}{|c|}{32.08 .00} \\
\hline 2 & 1 & 10 & 10 & 11 & 10 & 21 & 22 & 23 & 22 & 23 & 23 & 24 & 24 & 25 \\
\hline \multirow{7}{*}{ 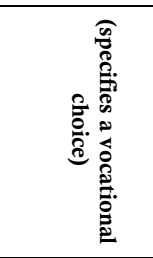 } & 2 & 10 & 9 & 9 & 10 & 22 & 23 & 23 & 24 & 24 & 23 & 22 & 23 & 23 \\
\hline & 3 & 9 & 9 & 8 & 8 & 20 & 22 & 21 & 22 & 23 & 23 & 23 & 24 & 25 \\
\hline & 4 & 10 & 10 & 10 & 10 & 20 & 22 & 22 & 23 & 23 & 23 & 22 & 23 & 24 \\
\hline & 5 & 10 & 10 & 9 & 9 & 20 & 22 & 22 & 23 & 24 & 24 & 25 & 25 & 26 \\
\hline & 6 & 10 & 9 & 10 & 9 & 20 & 21 & 22 & 22 & 23 & 23 & 22 & 23 & 23 \\
\hline & 7 & 10 & 10 & 11 & 12 & 22 & 23 & 24 & 24 & 24 & 24 & 25 & 26 & 27 \\
\hline & 8 & 10 & 10 & 9 & 10 & 20 & 21 & 22 & 22 & 23 & 22 & 23 & 22 & 23 \\
\hline \multicolumn{2}{|c|}{ Total of each session } & 79 & 77 & 77 & 78 & 165 & 176 & 179 & 182 & 187 & 185 & 186 & 190 & 196 \\
\hline \multicolumn{2}{|c|}{ Mean of each session } & 09.08 & 09.06 & 09.06 & 09.07 & 20.06 & 22 & 22.03 & 22.07 & 23.03 & 23.01 & 23.03 & 23.07 & 24.05 .00 \\
\hline \multicolumn{2}{|c|}{ Total Mean of each phase } & \multicolumn{3}{|c|}{38.07 .00} & & & & 110.09 .00 & & & & 94.0 & 06.00 & \\
\hline Mean of each 1 & & & 0,42152778 & & & & & 22.18 & & & & 1,003 & 472222 & \\
\hline 3 & 1 & 10 & 10 & 11 & 10 & 15 & 15 & 16 & 16 & 16 & 17 & 16 & 16 & 16 \\
\hline & 2 & 11 & 11 & 11 & 10 & 22 & 23 & 24 & 25 & 24 & 24 & 24 & 23 & 22 \\
\hline E. $\frac{\hat{2}}{8}$ & 3 & 11 & 11 & 12 & 11 & 24 & 24 & 25 & 24 & 25 & 25 & 25 & 24 & 23 \\
\hline 훙: & 4 & 10 & 10 & 10 & 10 & 24 & 24 & 23 & 24 & 25 & 25 & 25 & 23 & 22 \\
\hline 苞 & 5 & 10 & 10 & 10 & 10 & 23 & 24 & 24 & 25 & 25 & 26 & 25 & 23 & 22 \\
\hline 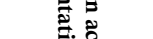 & 6 & 11 & 11 & 10 & 11 & 20 & 21 & 22 & 22 & 21 & 22 & 22 & 23 & 22 \\
\hline อ. & 7 & 10 & 11 & 12 & 11 & 22 & 24 & 24 & 23 & 24 & 24 & 25 & 24 & 23 \\
\hline & 8 & 11 & 12 & 12 & 13 & 20 & 22 & 23 & 22 & 23 & 23 & 24 & 23 & 22 \\
\hline Total of each $s$ & sion & 84 & 86 & 88 & 86 & 155 & 162 & 165 & 165 & 167 & 169 & 170 & 163 & 156 \\
\hline Mean of each 1 & ase session & 10.05 & 10.07 & 11 & 10.07 & 19.03 & 20.02 & 20.06 & 20.06 & 20.08 & 21.01 & 21.02 & 20.03 & 19.05 \\
\hline Total Mean of & ch phase & & 53.07 .00 & & & & & 101.03 .00 & & & & 82.0 & 01.00 & \\
\hline Mean of each 1 & & & 13.42 & & & & & 20.26 & & & & 20 & .52 & \\
\hline
\end{tabular}


The results presented in Table 1 shows that each subjects obtained a stable low mean score of exploration skills baseline conditions with an average score 13.27 for sub component narrowing choices, 9.67 for sub component specifies a vocational choice, and 13.42 for deciding an action implementation. These scores shows that subjects in the category of unskilled.

The scores of subjects career exploration skills for each sub components shows higher score after treated with career exploration guidance group using mind-mapping technique. In treatment phase, each subjects obtained a stable high scores of exploration skills with average score 30.86 for sub component narrowing choices, 22.18 for sub component specifies a vocational choice, and 20.26 for deciding an action implementation.

The stable condition in the treatment phase remain stable in the four sessions of maintenance, that is 32.8 for sub component narrowing choices, 23.65 for sub component specifies a vocational choice, and 20.52 for deciding an action implementation. This data affirm that the students' career exploration skills that had been improved in the guidance group using mind-mapping technique remain high and shows that students remain skilled.

Figure 1a, 1b, and 1c will shows the improvement of students' career exploration skills for each sub components in group.

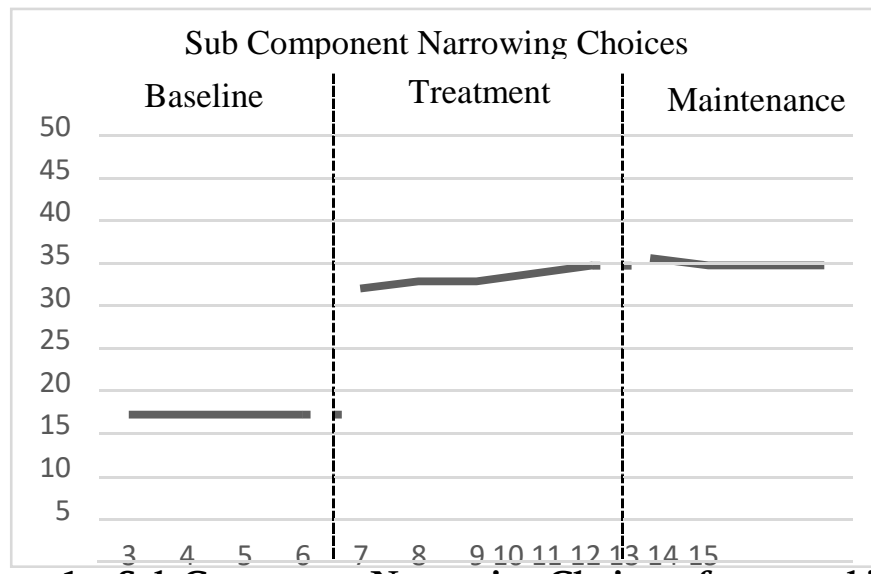

Figure 1a: Sub Component Narrowing Choices of group subjects

Figure 1a, b, and c visualize the graphs of career exploration skills' group scores in each sessions for each sub components. Higher points in each axis shows that there higher career exploration skills gained in the next session from the previous one. Figure la shows that in the sub component of narrowing choices, 8 subjects in the group overally shows a higher skills after being treated by using mind-mapping technique. The subjects shows that by visualizing their choices of variative occupations and major department, and linked it with their personal interests and capabilities, they then became aware of some aspects (circles) that are not link. Therefore subjects would revised their choices and limit it to one several relevant choices of occupations and major department that relevant to their personal interests and capabilities.

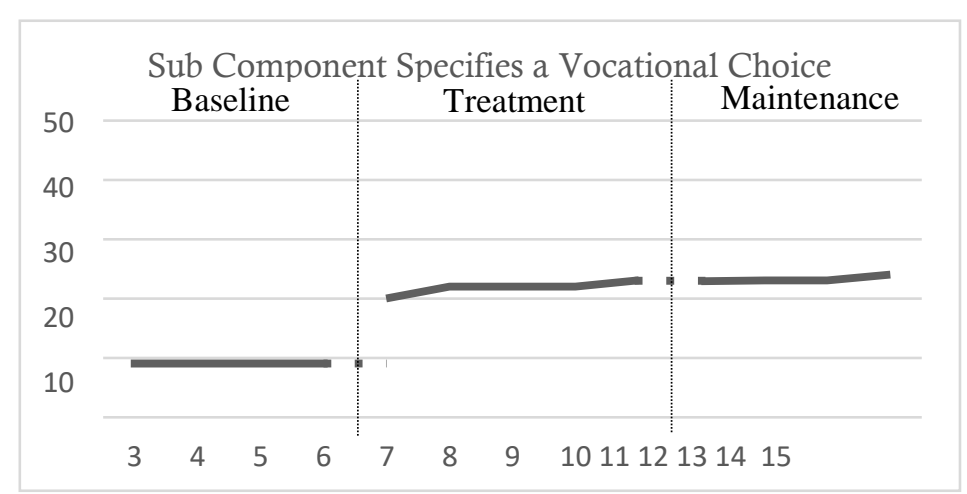

Figure 1b: Sub Component Specifies a Vocational Choice

Figure $1 \mathrm{~b}$ shows that in the sub component of specifies a vocational choice, 8 subjects shows that after observing their own mind-mapping drawings, they realize that some choices of occupations and major department are mostly unreachable because of some barriers such as financial, parents, school grade, or others. These conditions urge them to find one most rational that is most reachable and achieved by them. This explain how the subjects point can reach higher state of specifying a vocational choice. 


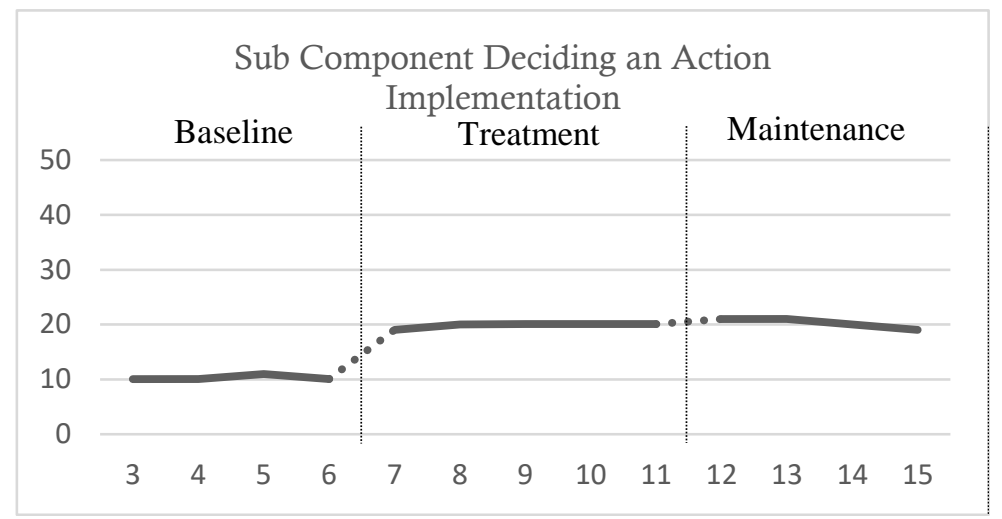

Figure 1c: Sub Component Deciding an Action Implementation

Figure 1c shows that by utilizing mind-mapping technique, 8 subjects in the group overally shows that they can define and decide an action implementation to achieve their goal of occupation and major department, which were difficult for them to decide at the baseline level because of so much variety of and unrealistic goals and choices they had.

\section{Conclusions}

The use of mind-mapping technique is effective for enhancing career exploration skills for 10th grader high school students. The eight subjects showed an increase in three sub components of career exploration skills. Thus, the implementation of mind-mapping technique effectively improves the career exploration skills individually or in group among high school students. High school counselors play an important role in engaging their guidance group utilizing mind-mapping technique. School counselor are required to ensure the benefits that mind-mapping can do in fostering high school student's career exploration, which in turn students can developed their career-related skills in a fun and creative experience and encourage their willingness and enthusiasm.

\section{Acknowledgments}

The researchers would like to thank to all the counselors in SMA Brawijaya Smart School for their openhanded in helping the implementations of this research. The researchers also very grateful for all the eight subjects willingness to be involved in this research. Last but not least, we would like to thanks to all the former researchers that have inspired us in doing a scientific research on career exploration and mind-mapping.

\section{References}

Agopsowicz, A., Robinson, C., Stinebrickner, R., \& Stinebrickner, T. R. (2017). Careers and mismatch for college graduates: College and non-college jobs. CHCP Working Paper.

Badan Pusat Statistik. (2018). Tingkat Pengangguran Terbuka (TPT) sebesar 5,34 persen. Retrieved December 25, 2018, from https://www.bps.go.id/pressrelease/2018/11/05/1485

Brown, N. W. (2018). Psychoeducational groups: Process and practice. Routledge.

Creswell, J. W. (2012). Planning, conducting, and ewaluating quantitative and qualitative research. Pearson, Boston, ISBN-13.

Davies, M. (2011). Concept mapping, mind mapping and argument mapping: what are the differences and do they matter? Higher Education, 62(3), 279-301.

Dewi, E. M. P., Djalal, N. M., \& Siswanti, D. N. (2017). The Influence Of "Edufair" Psychoeducation To Improve Student Career Maturity At Y Senior High School Of Makassar. In International Conference on Education, Science, Art and Technology (pp. 75-87).

Harahap, R. F. (2014). Duh, 87\% Mahasiswa Indonesia Salah Jurusan! Retrieved December 6, 2016, from https://news.okezone.com/read/2014/02/24/373/945961

Hariani, P. (2011). Analisis Penyerapan Tamatan Perguruan Tinggi Di Propinsi Sumatera Utara Tahun 2011. Jurnal Ilmiah Manajemen Dan Bisnis UMSU, 11(2), 139-157.

Johnson, B., Down, B., Le Cornu, R., Peters, J., Sullivan, A., Pearce, J., \& Hunter, J. (2014). Promoting early career teacher resilience: A framework for understanding and acting. Teachers and Teaching, 20(5), 530546.

Knaggs, C. M., Sondergeld, T. A., \& Schardt, B. (2015). Overcoming barriers to college enrollment, persistence, and perceptions for urban high school students in a college preparatory program. Journal of Mixed Methods Research, 9(1), 7-30.

Journal homepage: http://journal.redwhitepress.com/index.php/jles 
Kosine, N., \& Lewis, M. (2008). Growth and exploration: Career development theory and programs of study. Career and Technical Education Research, 33(3), 227-243.

Lau, P. L., Khan, A., Abdullah, H. S., \& Chew, F. P. (2011). The effectiveness of career exploration program for high school students. In International Conference on Humanities, Society and Culture (pp. 226-230).

Lent, R. W., Ezeofor, I., Morrison, M. A., Penn, L. T., \& Ireland, G. W. (2016). Applying the social cognitive model of career self-management to career exploration and decision-making. Journal of Vocational Behavior, 93, 47-57.

Liu, Y., Zhao, G., Ma, G., \& Bo, Y. (2014). The effect of mind mapping on teaching and learning: A metaanalysis. Standard Journal of Education and Essay, 2(1), 17-31.

Pascarella, E. T., \& Terenzini, P. T. (1991). How College Affects Students: Findings and Insights from Twenty Years of Research. Vol.[1]. San Francisco, California, Jossey-Bass.

Pesch, K. M., Larson, L. M., \& Seipel, M. T. (2018). Career certainty and major satisfaction: The roles of information-seeking and occupational knowledge. Journal of Career Assessment, 26(4), 583-598.

Rosser, A. (2015). Law and the realisation of human rights: Insights from Indonesia's education sector. Asian Studies Review, 39(2), 194-212.

Sampson, J. P., Osborn, D. S., Kettunen, J., Hou, P., Miller, A. K., \& Makela, J. P. (2018). The Validity of Social Media-Based Career Information. The Career Development Quarterly, 66(2), 121-134.

Sunanto, J., Takeuchi, K., \& Nakata, H. (2005). Pengantar penelitian dengan subjek tunggal. Center for Research on International Cooperation in Educational Development (CRICED) University of Tsukuba.

Vignoli, E. (2015). Career indecision and career exploration among older French adolescents: The specific role of general trait anxiety and future school and career anxiety. Journal of Vocational Behavior, 89, 182191. 